\title{
Development of physics e-module based on integrated project- based learning model with Ethno-STEM approach on smartphones for senior high school students
}

\author{
Yulkifli Yulkifli a *, Yohandri Yohandri ${ }^{b}$, Hasbi Azis ${ }^{c}$ \\ Universitas Negeri Padang. Jl. Prof Hamka, Padang 25131, Indonesia \\ ayulkifliamir@fmipa.unp.ac.id; b yohandri@fmipa.unp.ac.id; chasbiazis14@gmail.com \\ * Corresponding Author.
}

Received: 9 December 2021; Revised: 25 January 2022; Accepted: 30 January 2022

\begin{abstract}
Standard competency of graduate students of class XI in Physics learning is considered not optimal. One of the contributing factors is the unavailability of the Physics E-Module, which contains model steps and is integrated with a learning approach in order to direct students in active learning. This study aims to produce a Physics E-Module based on an integrated project-based learning model with an Ethno-STEM approach on smartphones for class XI high school students with valid, practical, and effective criteria. This is development research using the Plomp development model consisting of three stages: Preliminary Research, Development or Prototyping Phase, and Assessment Phase. The instruments used in this research include three questionnaires for preliminary study, validity and practicality, attitude observation sheets, written test sheets, and skills assessment sheets. The result obtained was a Physics E-Module based on an integrated project-based learning model with the Ethno-STEM approach on smartphones for class XI high school students who meet valid, practical, and effective criteria.

Keywords: E-Module, Project Based Learning, Ethno-STEM Approach
\end{abstract}

How to Cite: Yulkifli, Y., Yohandri, Y., \& Azis, H. (2022). Development of physics e-module based on integrated project-based learning model with Ethno-STEM approach on smartphones for senior high school students. Momentum: Physics Education Journal, 6(1), 93-103. https://doi.org/10.21067/mpej.v6i1.6316

\section{Introduction}

Physics is a science that studies natural phenomena in everyday life (Kapucu, 2017) and is one of the subjects contained in the 2013 Curriculum in Indonesia. Currently, Physics learning is in the $21^{\text {st }}$-century learning paradigm, which aims to form human resources with the ability to think critically, creatively, collaboratively and communicatively (Asrizal et al., 2019). 21 ${ }^{\text {st }}$-century learning can also hone and develop students' skills in achieving learning goals (Asrizal et al., 2020).

The role of digital technology is also needed in facing $21^{\text {st }}$-century education. As it is today, the use of smartphones is familiar to both students and teachers (Bukhori et al., 2019). Smartphones can be used as learning resources that can support students in obtaining information and supporting the achievement of a learning goal (Alfawareh \& Jusoh, 2017). One of the learning media that can be used as a learning resource on smartphones is the E-Modul.

E-Module is a learning media providing systematic learning so that students can learn independently to achieve certain learning goals, which are presented in electronic form containing interactive animations, videos, and audio (I. S. Sari et al., 2021; Sofyan et al., 2019). E-Module can also be used as a learning resource to support the implementation of the learning process anytime and anywhere (Rahmawati et al., 2021). In addition to learning media, the use of learning models can also affect the learning process and can make students active in accordance with the objectives of 
the 2013 curriculum. One of the learning models that are in accordance with the objectives of the 2013 curriculum is the project-based learning model.

The project-based learning model is a learning model that involves students being active in the learning process by directing students to design and produce real projects that encourage various student competencies (Sharma et al., 2020). The project-based learning model is also a learning model that can improve student competence in terms of attitude, knowledge, and skill competencies (Amamou \& Cheniti-Belcadhi, 2018). In addition to learning models, learning approaches can also support learning and improve the quality of education, especially in knowledge and skill competencies. One approach that can support this is the Ethno-STEM approach.

The ethno-STEM approach is one that collaborates the STEM, and the ethnoscience approaches. The Ethno-STEM approach is an approach that involves STEM aspects that are based on local culture and typical knowledge of the surrounding community to improve students' abilities in critical, creative and collaborative aspects (I. S. Sari et al., 2021). In addition, the application of the Ethno-STEM approach in learning can improve science process skills (Sudarmin et al., 2021). The integration of the project-based learning model with the Ethno-STEM approach is considered suitable in the learning process because science learning that is integrated with local community knowledge can increase students' understanding of science concepts in everyday life (Muttaqiin et al., 2021). This is because there are several research results related to the integrated project-based learning model of the Ethno-STEM approach, which concludes that the application of learning using the integrated project-based learning model of the Ethno-STEM approach has a positive effect and can improve the learning competence of students (Sudarmin et al., 2019, 2021; Sumarni \& Kadarwati, 2020). However, none of these studies has yet been implemented in the form of Physics E-Modules, so research related to project-based learning model with the Ethno-STEM approach is needed.

Learning resources are good learning media with valid, practical, and effective criteria. The good E-Modul must be previously tested for the level of validity, practicality, and effectiveness. Experts carry out validity tests to assess the feasibility of a product. If the product is not valid, then the product will be revised to meet the valid criteria (Septiani \& Yulkifli, 2021). After the product is considered valid, it will be continued by testing the product's practicality related to the ease of use of the product and in terms of an attractive and effective product (Adriani et al., 2021). Furthermore, the product will be tested for the effectiveness value, which is the level of success of a product after it is used in the learning process (IImi et al., 2021). Based on the explanation above and to support the 2013 curriculum and 21st-century learning objectives, the purpose of this research is to design and produce a Physics E-Module based on integrated project-based learning with an Ethno-STEM approach on smartphones for high school students in class XI.

\section{Methods}

This research is an R\&D (Research and Development) research using the Plomp development model. The Plomp development model consists of several phases: preliminary research, development or prototyping, and assessment (Amawa et al., 2019; Plomp \& Nieveen, 2007). The preliminary research stage is carried out to obtain information related to problems in learning and find the characteristics of students (Satria et al., 2019). Activities at this stage consist of an analysis of learning activities, graduate competency standards, and students. The data collection instruments applied are a teacher and student questionnaire sheet and an interview sheet.

The second phase is the development or prototyping phase. This phase aims to design, evaluate, and revise the E-Module to be feasible to apply in learning. After the E-Modul is ready to be designed, it will be evaluated on a micro-scale to produce a valid and practical one. This evaluation is also known as formative evaluation, which consists of several steps: First, Self-Evaluation, namely revising the product by yourself using a self-evaluation sheet; Second, Expert Review, namely the assessment by experts of the product developed using the product validity assessment sheet. Three validators assessed the product validity assessment. Product validity assessment indicators consist of the components of the feasibility of the content of the material, the content of the construction, 
language, and appearance. The product validity analysis technique uses the Aiken's $V$ equation with calculations; if the value obtained is 0.6 , then the product is valid, but if the value is 0.6 , then the product is invalid; Third, One to one evaluation, namely the individual product practicality test. The practicality assessment at this stage was assessed by three students with different abilities using a practicality assessment sheet; Fourth, Small Group Evaluation, namely product practicality test in small groups. The practicality assessment at this stage was assessed by ten students using a practicality assessment sheet; and Fifth, Field Test, namely testing the product into classroom learning and taking the practicality value of the product using a practicality assessment sheet that 38 students and 2 Physics teachers assessed.

The third one in this research is the Assessment Phase. This phase aims to determine whether the developed product is effectively used in learning. Product effectiveness analysis is taken from the achievement of students after the product is applied in learning. Students' achievement is seen from several competencies, namely the competence of attitudes, knowledge, and skills. The product is considered effective on students' attitudes if the overall attitude of students is in a Good category (B). The assessment of student knowledge is taken using the Gain Score equation analysis to see the increase in student knowledge (Andanawarih et al., 2019). E-Module can be said to be effective if the gain score obtained is in the medium category. E-Modules can also be said to be effective if overall students obtain classical completeness of more than $85 \%$ (Satria et al., 2019).

\section{Results and Discussion}

The research results on the development of E-Modules based on the integrated project-based learning model with Ethno-STEM approach on smartphones are sorted by the phases of the Plomp development model, namely the preliminary research, developing or prototyping, and the assessment phase. The preliminary research phase is the initial phase of the research. At this stage, several activities are carried out to analyze the problems contained in learning and determine students' characteristics.

Analysis of learning activities is carried out to obtain information related to learning needs. Learning activities consist of several indicators (Yulia et al., 2020), namely; (1) Preliminary activities; (2) The core activities consist of applying a learning approach and using learning resources; and (3) Closing activities. From the results of the analysis that has been carried out, there are problems to be considered, such as the implementation of learning approaches and learning resources used in core activities. The results of the analysis of the learning approach and the use of learning resources get less value. It shows that the teacher lacks in implementing the learning approach and maximizing the use of learning resources to direct the students' activities. Regarding the analysis of activities, the introduction and closing activities received good marks.

The next analysis is the analysis of graduate competency standards. Based on the results of the analysis obtained, students are lack knowledge (factual, conceptual, procedural, and metacognitive). This is because teachers still dominate learning, and they have not maximized the use of appropriate learning models and approaches so that the knowledge competence of students is less trained. In addition, information obtained from teacher interviews shows that teachers have never developed learning resources other than LKS available in schools. Learning resources based on a learning model can direct student activities and learning resources that are integrated with an approach to increase knowledge competence. This needs to be done so that Physics learning is useful in developing the experience and competence of students.

Student analysis aims to determine the characteristics of these students by looking at several indicators. Based on the analysis that has been done, two indicators are considered lacking, namely, the indicators of knowledge and learning motivation. Students can still not identify facts related to physical phenomena around them. This is in line with the results of the analysis of graduate competency standards obtained previously that students are still lacking in knowledge. Then on indicators of learning motivation, problems need to be overcome by presenting interesting and focused learning on students. Student analysis was also carried out to see how they use of smartphones in learning 
was carried out. This analysis found that the use of smartphones for students in learning was rated high. This can be an opportunity to apply learning resources on smartphones in learning, so that they are in accordance with students' learning styles.

The preliminary research results show that the learning resources that can increase students' knowledge competence and direct students to be more active in learning according to students' learning styles are needed. Therefore, the researcher feels that it is necessary to have a Physics EModule based on a smartphone's integrated project-based learning model with the Ethno-STEM approach. Previously, researchers had conducted preliminary research on three schools in Padang regarding this matter and concluded that it was necessary to develop an E-Module Based on an integrated project-based learning model with an Ethno-STEM approach (Azis \& Yulkifli, 2021).

The developing or prototyping phase is carried out after the preliminary research activities. Products that are developed are immediately designed by referring to the preliminary research results obtained. The product developed is an e-module with a structure consisting of Title, Table of Contents, Concept Map, KI, KD, and Learning Objectives; Introduction, Learning Materials, Tasks and Exercises, Summary, Glossary, Evaluation, and Material Index. Furthermore, the designed E-Module is evaluated in a formative manner. The product is designed using Adobe Flash CS 6 software. Adobe Flash CS 6 software is considered suitable for loading electronic learning media. This refers to previous research that concluded that Adobe Flash software has many and is suitable for developing electronic learning media such as E-Modules (IImi et al., 2021). E-Modules that have been designed with Adobe Flash CS 6 software will be applied via digital smartphone devices, where E-Modules will direct students to take advantage of several features found on smartphones, such as being a measuring tool.

The self-evaluation stage is carried out before the validator validates the product. The researcher re-examined the product by examining the structure, the content, and the language of the E-Modul. The results of the self-evaluation show that there are several errors in the E-Modul, such as errors in language use, typing errors, and unclear images. These errors were corrected prior to the Expert Review stage. The designed E-Modul contains a cover consisting of the images contained in the E-Modul, as shown in Figure 1.

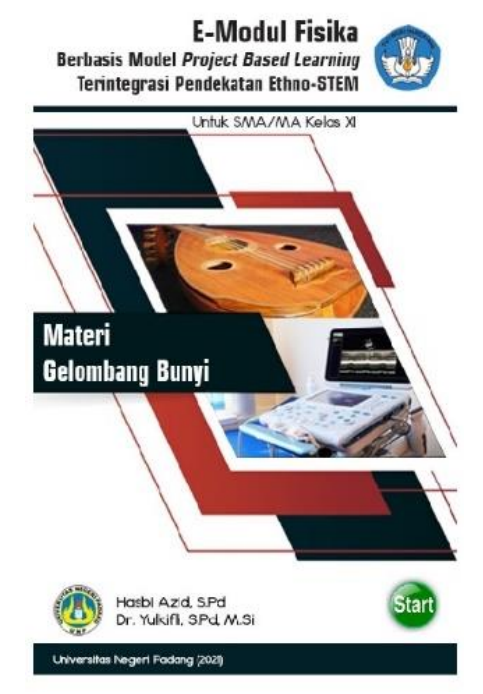

Figure 1. Physics E-Modul Cover

The designed E-Module contains the content related to information about local community knowledge in an area (original science) and is then linked to current scientific science and technology (Ethno-STEM). The content of Ethno-STEM in the E-Modul contains specific knowledge of the community regarding the phenomena that exist in the area or the culture that exists in an area, both from art tools such as music and visual arts to habits that have become cultural. The knowledge contained in the area is called original science, which is then transformed into scientific science that students learn in physics learning. After students know the transformation of original science into 
scientific science, the E-Modul directs students to find out the connection or use of science to current technology. The content is loaded on the E-Modul and aims to increase students' knowledge regarding the phenomena or physics around them and the role of physics in current technology, which is expected to stimulate students' creativity. The design of the E-Modul can be seen in Figure 2.
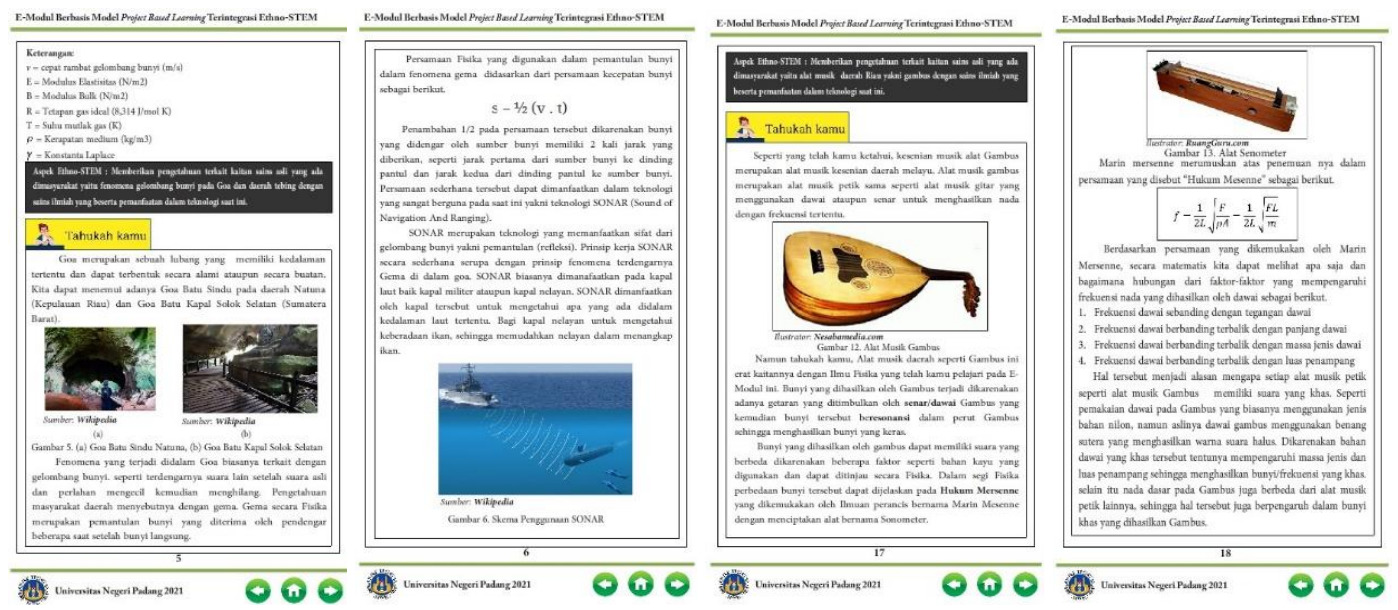

Figure 2. E-Module Material related to Ethno-STEM

The designed E-Module also includes a project-based learning model phase in directing students to be more active in creating projects or products as one of the learning outcomes. The learning content of the project-based learning model contained in the E-Modul is designed regularly following the syntax of the project-based learning model. Ethnoscience knowledge is contained in the syntax "start with the essential question," which aims to stimulate students' knowledge in doing a project by applying the principles of Physics they have learned. The learning content also directs students to use their smartphones to measure something related to the projects they make. In addition, students are also directed to analyze the physics principles they use in the project into their use in current technology. The learning model in the E-Module aims to direct students to create a project that is in accordance with the syntax and also to hone students' skills such as creative, critical, communicative, and collaborative thinking skills in solving a problem both individually and in groups. The E-Module design related to the project-based learning model can be seen in Figure 3.
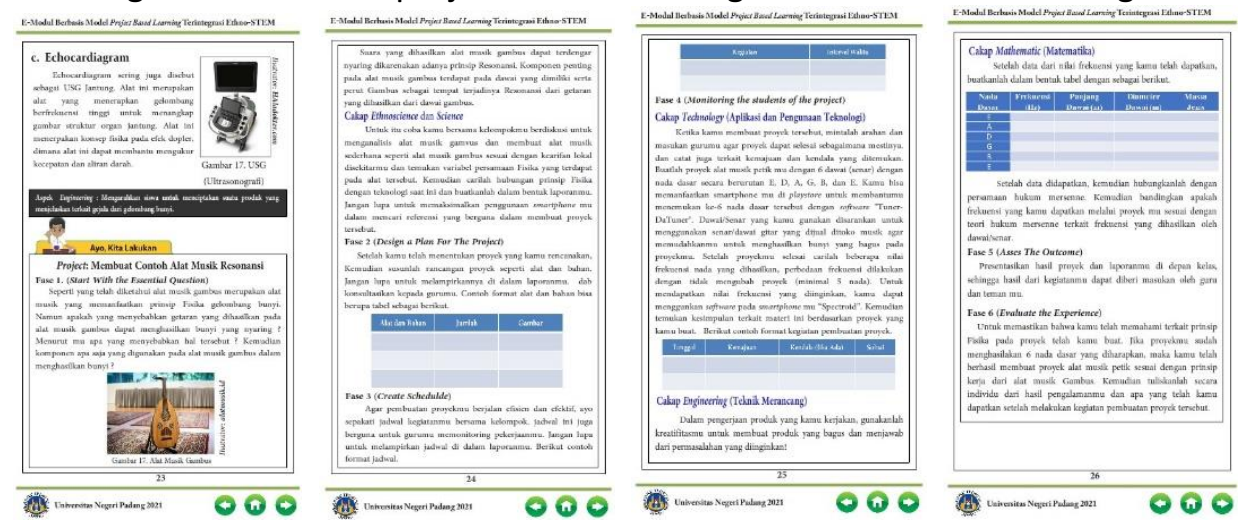

Figure 3. The phase of the Project-Based Learning Model

The designed E-Module is also equipped with a self-evaluation for students which is located at the end. The Evaluation feature in the E-Modul serves to provide questions related to the material in the E-Modul in an objective format. Students can solve the questions contained in the evaluation section, and after completing the evaluation questions, students will receive scores obtained directly on the E-Module. Evaluation features can be seen in Figure 4. 


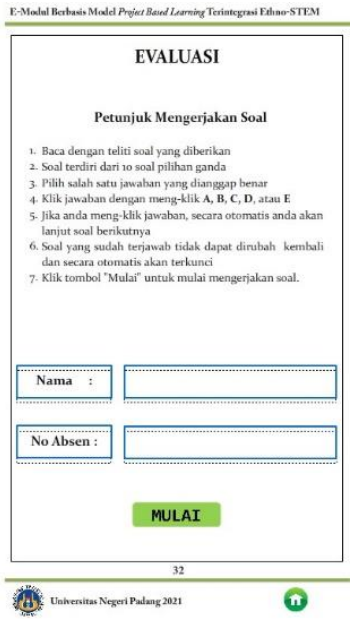

(a)

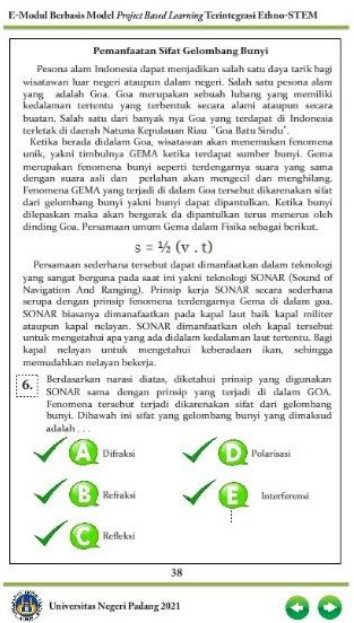

(b)



(c)

Figure 4. Evaluation Parts in the E-Module (a) Instructions for Working on Questions (b) Evaluation Questions (c) Display of Evaluation Values

The E-Module that has been designed and revised according to the self-evaluation results is called prototype one and is continued at the expert review phase. The E-Module will be validated by three validators using the product validity assessment sheet in the phase. Before the validators assess the validity of the product, the validation assessment sheet has been said to be valid. The product validity test includes several aspects, namely material content, construction content, language, and appearance. The results of the E-Modul validity test can be seen in Table 1.

Table 1. Validity Test Results of Product

\begin{tabular}{cccc}
\hline \multirow{2}{*}{ No. } & Valued Aspects & \multicolumn{2}{c}{ Expert Validator } \\
\cline { 3 - 4 } & & Aiken's V Value & Criteria \\
\hline 1. & E-Module content & 0.78 & Valid \\
2. & E-Module construction content & 0.80 & Valid \\
3. & E-Module Language & 0.75 & Valud \\
4. & E-Module Interface & 0.88 & Valid \\
\hline \multicolumn{2}{r}{ Average } & 0.80 & Valid \\
\hline
\end{tabular}

Based on Table 1, the E-Module has been said to be valid by obtaining a V value of 0.80 . This shows that the E-Module is appropriate based on each of its components and can be used in learning. Then the E-Module was revised according to the validator's suggestions, such as the use of clear language, E-Module syntax, and the structure of the E-Module. The results of the expert review are named prototype 2 .

Products that have been valid are continued to the one-to-one evaluation phase. The phase involved three students of class XI MIPA 1 SMAN 1 Tanjungpinang with different abilities. Before conducting an assessment and product practicality, students are asked to read and understand the EModul well. The results of the practicality value of the E-Modul at the one-to-one evaluation stage are listed in Table 2.

Table 2. The practicality of E-Module at the one-to-one evaluation stage

\begin{tabular}{|c|c|c|c|}
\hline No. & Indicator & Value (\%) & Category \\
\hline 1. & Usable & 89.71 & Very Practical \\
\hline 2. & Easy to use & 86.46 & Very Practical \\
\hline 3. & Appealing & 85,7 & Very Practical \\
\hline \multirow[t]{2}{*}{4.} & Cost effective & 85,42 & Very Practical \\
\hline & Average & 86.69 & Very Practical \\
\hline
\end{tabular}

Table 2 shows that the one-to-one evaluation practicality assessment results obtained an average value of $86.69 \%$, which is in the very practical category. This shows that the E-Module is easy 
to use, attractive, and efficient. The results of the assessment at the one-to-one evaluation phase are called prototype 3 . Then the prototype testing is continued at the small group evaluation phase by involving ten randomly selected students of class XI MIPA 3 SMAN 1 Tanjungpinang. The results of the E-Modul practicality assessment at the small group evaluation phase can be seen in Table 3 .

Table 3. The practicality of E-Module at the small group evaluation stage

\begin{tabular}{cllcc}
\hline No. & & Indicator & Value (\%) & Category \\
\hline 1. & Usable & & 81.00 & Very Practical \\
2. & Easy to use & & 81.88 & Very Practical \\
3. & Appealing & & 83.93 & Very Practical \\
4. & Cost effective & & 81.88 & Very Practical \\
\hline & & Average & 82.17 & Very Practical \\
\hline
\end{tabular}

Table 3 shows that the E-Module is very practical in all four aspects. This shows that the EModule is usable, easy to use, attractive, and efficient. The results of the small group evaluation stage are called prototype four. Furthermore, prototype four was assessed for its practicality at the field test stage. In the field test stage, the practicality of the E-Module will be assessed by 2 Physics teachers and 38 students of class XI MIPA 7 SMAN 1 Tanjungpinang. Previously, E-Modules would be taught first in three meetings, then teachers and students were asked to assess the practicality of using E-Modules in learning. The results of the practicality of the E-Modul at the field test stage from the teacher's response can be seen in Table 4.

Table 4. The practicality of E-Module on Field Test from Teacher Response

\begin{tabular}{|c|c|c|c|}
\hline No. & Indicator & Value (\%) & Category \\
\hline 1. & Usable & 85.00 & Very Practical \\
\hline 2. & Easy to use & 87.50 & Very Practical \\
\hline 3. & Appealing & 83.93 & Very Practical \\
\hline 4. & Cost effective & 84.38 & Very Practical \\
\hline \multicolumn{2}{|r|}{ Average } & 85.20 & Very Practical \\
\hline
\end{tabular}

Table 4 shows that the E-Module is in very practical criteria with an average value of $85.20 \%$. From these results, it was concluded that the E-Modul was declared usable and easy to use. The EModul was also seen from the responses of students after using it. The results of student responses to the practicality of E-Modules are described in Table 5.

Table 5. The practicality of E-Module on Field Test from Student Response

\begin{tabular}{clcc}
\hline No. & \multicolumn{1}{c}{ Indikator } & Nilai (\%) & Kategori \\
\hline 1. & Usable & 82,50 & Very Practical \\
2. & Easy to use & 80,25 & Very Practical \\
3. & Appealing & 80,71 & Very Practical \\
4. & Cost effective & 82,75 & Practical \\
\hline & Average & 81,55 & Very Practical \\
\hline
\end{tabular}

Based on Table 5, the practicality of the e-module based on the responses of students in the field test got a score of $81.55 \%$ with a very practical category. Based on the practical results of the EModule at the field test stage from the results of the teacher and student responses, it was concluded that the E-Module was stated to be usable, easy to use, attractive and efficient.

The Assessment Phase is carried out to determine the value of the effectiveness of using EModules in learning. The assessment phase is carried out by looking at the value of students on the competence of attitudes, knowledge and skills. Attitude competency assessment is taken from each meeting through student attitude observation sheets. The assessment of students was carried out at three meetings of the sound wave material. The indicators assessed on the attitude competence of students consist of religious indicators (RG), Curious (RIT), Thorough (TL), and Responsibility (TJ). The results of the student attitude competency assessment are shown in Figure 5. 


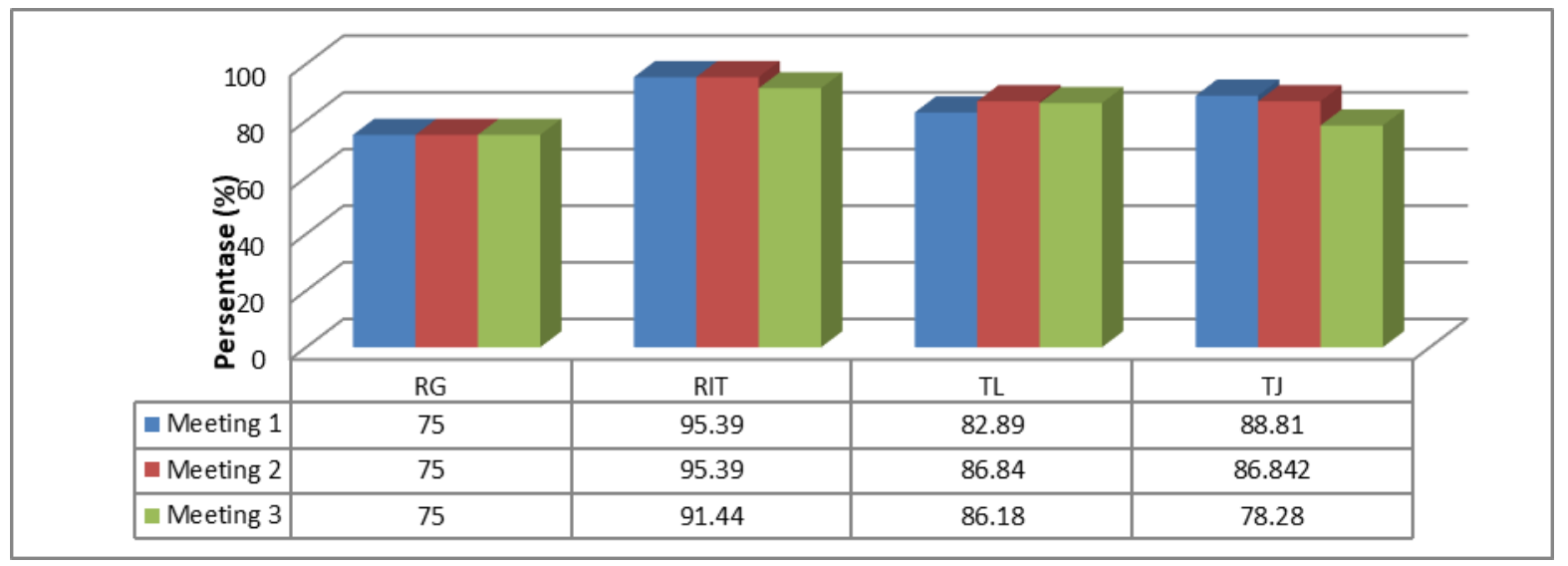

Figure 5. Graph of Student Attitude Competency Assessment

Based on Figure 5, the student's attitude competency assessment results show that the student's attitude competency is in a good category. This shows that learning using E-Modules is said to be effective in the attitude competence of students. Assessment of knowledge competence can be seen from the student's knowledge test.

The assessment was carried out using a pretest and posttest using an e-module based on an integrated project-based learning model with the Ethno-STEM approach. Students' knowledge is increased through data processing using the $\mathrm{N}$-Gain equation. Overall, the average value of the pretest of students is 50.00 , and the average value of the posttest of students is 77.37 . The N-Gain data processing on the competence of students got a value of 0.62 , which was in the medium category. Regarding maximum completeness, overall students also experienced an increase, where there were no students who achieved classical completeness on the pretest while classical completeness on the posttest was $86.84 \%$. From the competency analysis that has been carried out, these results show that learning using the E-Module is effective and can increase students' knowledge. The results obtained are in line with M. P. Sari et al. (2021) research, which states that the use of E-Module in learning can increase students' knowledge. E-Modules in learning is considered easier and friendly because students can use the E-Modules anytime and anywhere via smartphones to achieve the expected learning goals (Klein et al., 2021). Furthermore, the use of the project-based learning model can also increase students' knowledge because, in addition to students gaining knowledge through the Ethno-STEM approach, they also gain knowledge independently through the project-based learning model stage in making a project as a result of the students' knowledge (Sudarmin et al., 2019, 2021). The use of project-based learning models in learning is also in line with the concept of 21st Century Education (Allison, 2018). Skill competency assessments are taken as research supporting data as long as students work on projects in each group. The competency assessment results of student's skills can be seen in Table 6 .

Table 6. Results of Student Skill Competency Analysis

\begin{tabular}{|c|c|c|c|c|c|c|c|c|c|c|c|c|c|}
\hline \multirow{2}{*}{ No. } & \multirow{2}{*}{ Stage } & \multicolumn{6}{|c|}{ Group Score } & \multicolumn{6}{|c|}{ Group Final Score } \\
\hline & & 1 & 2 & 3 & 4 & 5 & 6 & 1 & 2 & 3 & 4 & 5 & 6 \\
\hline 1. & Report Assessment (15\%) & 91 & 85 & 85 & 89 & 89 & 94 & 13.6 & 12.9 & 12.9 & 13.4 & 13.4 & 14.2 \\
\hline 2. & Implementation (30\%) & 95 & 95 & 80 & 95 & 90 & 100 & 28.5 & 28.5 & 24 & 28.5 & 27 & 30 \\
\hline 3. & Reporting (20\%) & 81 & 81 & 62 & 75 & 68 & 68 & 16.5 & 16.2 & 12.5 & 15 & 13.8 & 13.8 \\
\hline 4. & Presentation (15\%) & 79 & 79 & 63 & 75 & 77 & 72 & 11.9 & 11.9 & 9.6 & 11.2 & 11.6 & 10.9 \\
\hline 5. & Final Product (20\%) & 87 & 93 & 100 & 93 & 93 & 81 & 17.5 & 18.8 & 20 & 18.8 & 18.8 & 16.2 \\
\hline \multicolumn{8}{|c|}{ Total Score } & 88 & 87,6 & 79 & 86.9 & 84.6 & 85.1 \\
\hline
\end{tabular}

Based on Table 6, the average value of students' skills in project work is in the good predicate. This is because the E-Module is effective in its implementation and can increase the activities of students in the learning process. The use of project-based learning models in learning makes students more active and triggers curiosity in completing the projects they are working on (Sudarmin 
et al., 2021; Tresnawati et al., 2021). The use of the Ethno-STEM approach project-based learning model in learning can also hone the skills and creativity of students in doing projects, both individually and in groups (Sumarni \& Kadarwati, 2020).

\section{Conclusion}

Based on the development research applying the Plomp development model, it was concluded that the preliminary research stage needs the Physics E-Module based on an integrated projectbased learning model with an Ethno-STEM approach on a smartphone. The E-Module design is useful for generating students' excitement in learning and honing students' skills. The designed E-Module has met the valid and practical criteria and is in the effective criteria assessed on the competence of attitudes, knowledge, and skills. This E-Module is designed to make it easier for students to learn and direct students to be more active in learning Physics.

\section{Acknowledgement}

The author would like to thank Universitas Negeri Padang since this research is part of the 2021 Master Thesis Research (PTM) with Contract number: 719/UN35.13/LT/2021. Thank you to all supportive parties in this research.

\section{References}

Adriani, D., Azhar, M., Dj, L., Putra, A., \& Yerimadesi. (2021). Validity and practicality level of acidbase electronic module based on structured inquiry containing three levels of chemical representation for senior high school student. Journal of Physics: Conference Series, 1788(1), 012038. https://doi.org/10.1088/1742-6596/1788/1/012038

Alfawareh, H. M., \& Jusoh, S. (2017). The use and effects of smartphones in higher education. International Journal of Interactive Mobile Technologies (IJIM), 11(6), 103. https://doi.org/10.3991/ijim.v11i6.7453

Allison, J. M. (2018). Project based learning to promote 21st century skills: An action research study [William \& Mary]. https://doi.org/10.25774/w4-m5xm-wc95

Amamou, S., \& Cheniti-Belcadhi, L. (2018). Tutoring in project-based learning. Procedia Computer Science, 126, 176-185. https://doi.org/10.1016/j.procs.2018.07.221

Amawa, I., Yerizon, Y., Sri, N., \& Putra, R. T. (2019). Development of students' worksheet based on APOS theory approach to improve student achievment in learning system of linear equations. International Journal of Scientific Dan Technology Research, 8(4), 287-292.

Andanawarih, M., Diana, S., \& Amprasto, A. (2019). The implementation of authentic assessment through project-based learning to improve student's problem solving ability and concept mastery of environmental pollution topic. Journal of Physics: Conference Series, 1157, 022116. https://doi.org/10.1088/1742-6596/1157/2/022116

Asrizal, Amran, A., Ananda, A., \& Festiyed. (2019). Effects of science student worksheet of motion in daily life theme in adaptive contextual teaching model on academic achievement of students. Journal of Physics: Conference Series, 1185, 012093. https://doi.org/10.1088/1742$6596 / 1185 / 1 / 012093$

Asrizal, Desnita, \& Darvina, Y. (2020). Need analysis to develop electronic enrichment book of Physics based on contextual teaching and environmental potential. Journal of Physics: Conference Series, 1481, 012123. https://doi.org/10.1088/1742-6596/1481/1/012123

Azis, H., \& Yulkifli. (2021). Preliminary research in the development of smartphone-based e-module learning materials using the ethno-STEM approach in 21st century education. Journal of Physics: Conference Series, 1876(1), 012054. https://doi.org/10.1088/1742$6596 / 1876 / 1 / 012054$

Bukhori, B., Said, H., Wijaya, T., \& Mohamad Nor, F. (2019). The effect of smartphone addiction, 
achievement motivation, and textbook reading intensity on students' academic achievement. International Journal of Interactive Mobile Technologies (IJIM), 13(09), 66. https://doi.org/10.3991/ijim.v13i09.9566

Ilmi, R., Arnawa, I. M., Yerizon, \& Bakar, N. N. (2021). Development of an android-based for math emodule by using adobe flash professional CS6 for grade $\mathrm{X}$ students of senior high school. Journal of Physics: Conference Series, 1742(1), 012026. https://doi.org/10.1088/1742$6596 / 1742 / 1 / 012026$

Kapucu, S. (2017). Predicting physics achievement: attitude towards physics, self-efficacy of learning physics, and mathematics achievement. Asia-Pacific Forum on Science Learning \& Teaching, 18(1).

Klein, P., Ivanjek, L., Dahlkemper, M. N., Jeličić, K., Geyer, M.-A., Küchemann, S., \& Susac, A. (2021). Studying physics during the COVID-19 pandemic: Student assessments of learning achievement, perceived effectiveness of online recitations, and online laboratories. Physical Review Physics Education Research, 17(1), 010117. https://doi.org/10.1103/PhysRevPhysEducRes.17.010117

Muttaqiin, A., Murtiani, M., \& Yulkifli, Y. (2021). Is integrated science book with ethno-STEM approach needed by secondary school students? Journal of Physics: Conference Series, 1788(1), 012048. https://doi.org/10.1088/1742-6596/1788/1/012048

Plomp, T., \& Nieveen, N. (2007). An introduction to educational design research. Proceedings of the Seminar Conducted at the East China Normal University, Shanghai (PR China), 23-26.

Rahmawati, F., Sarwanto, S., \& Budiawanti, S. (2021). Needs analysis of physics e-module based on hybrid-PBL model on critical thinking skills improvement. Momentum: Physics Education Journal, 175-181. https://doi.org/10.21067/mpej.v5i2.5740

Sari, I. S., Lestari, S. R., \& Sari, M. S. (2021). Preliminary study of guided inquiry-based e-module development based on research results to improve student's creative thinking skills and cognitive learning outcomes. AIP Conference Proceedings, 060006. https://doi.org/10.1063/5.0043320

Sari, M. P., Oktavia, R., \& Arif, K. (2021). Developing user-friendly e-module hyper-content on atomic structure and periodical properties of elements. Journal of Physics: Conference Series, 1940(1), 012112. https://doi.org/10.1088/1742-6596/1940/1/012112

Satria, H., Yulkifli, Y., \& Ramli, R. (2019). Development of natural science books inquiry based learning model with character contents. Journal Of Research And Method In Education, 9(3), 49-56. https://doi.org/10.9790/1959-0903014956

Septiani, T., \& Yulkifli. (2021). Validity of student worksheet inquiry based learning model with multirepresentation approach integrated scientific literacy for grade XI physics learning on 21 st century. Journal of Physics: Conference Series, 1876(1), 012087. https://doi.org/10.1088/1742$6596 / 1876 / 1 / 012087$

Sharma, A., Dutt, H., Venkat Sai, C. N., \& Naik, S. M. (2020). Impact of project based learning methodology in engineering. Procedia Computer Science, 172, 922-926. https://doi.org/10.1016/j.procs.2020.05.133

Sofyan, H., Anggereini, E., \& Saadiah, J. (2019). Development of e-modules based on local wisdom in central learning model at kindergartens in Jambi City. European Journal of Educational Research, 8(4), 1137-1143. https://doi.org/10.12973/eu-jer.8.4.1137

Sudarmin, S., Mursiti, S., Sarwi, S., \& Listiaji, P. (2021). Secondary metabolite learning model from Taxus sumatrana with ethnoscience integrated inquiry using online system and google form application. Journal of Physics: Conference Series, 1918(3), 032025. https://doi.org/10.1088/1742-6596/1918/3/032025

Sudarmin, S., Sumarni, W., Rr. Sri Endang, P., \& Sri Susilogati, S. (2019). Implementing the model of project-based learning : integrated with ETHNO-STEM to develop students' entrepreneurial 
characters. Journal of Physics: Conference Series, 1317(1), 012145.

https://doi.org/10.1088/1742-6596/1317/1/012145

Sumarni, W., \& Kadarwati, S. (2020). Ethno-stem project-based learning: its impact to critical and creative thinking skills. Jurnal Pendidikan IPA Indonesia, 9(1), 11-21. https://doi.org/10.15294/jpii.v9i1.21754

Tresnawati, N., Saleh, I., Sudarmin, \& Wardani, S. (2021). Science Batik Ciwaringin: The implementation of ethno-STEM PjBL model in learning biotechnology at PGSD students. Journal of Physics: Conference Series, 1842(1), 012063. https://doi.org/10.1088/1742$6596 / 1842 / 1 / 012063$

Yulia, S. R., Pratiwi, Y., \& Ramli, R. (2020). Needs analysis in development of physics handout based on STEM approach for 11th grade of senior high school. Journal of Physics: Conference Series, 1481(1), 12054. https://doi.org/10.1088/1742-6596/1481/1/012054 